\section{Trends of chronic health effects associated to pesticide use in fruit farming regions in the state of Ceará, Brazil}

\author{
Tendências de agravos crônicos à \\ saúde associados a agrotóxicos em \\ região de fruticultura no Ceará, Brasil
}

\section{Raquel Maria Rigotto'}

\section{Ageo Mário Cândido da Silva"}

Marcelo José Monteiro Ferreira'

Islene Ferreira Rosa'

\section{Ada Cristina Pontes Aguiar}

'Universidade Federal do Ceará, Community Health Department of the Medical School - Fortaleza (CE), Brazil.

"Universidade Federal do Mato Grosso. Instituto de Saúde Coletiva Cuiabá (MT), Brazil.

Corresponding author: Marcelo José Monteiro Ferreira. Rua Professor Costa Mendes, 1608, Bloco Didático, 5 Andar, Bairro Rodolfo Teófilo, CEP: 60430-140 - Fortaleza (CE), Brazil. E-mail: sbribous@ hotmail.com

Financing source: Study financed by CNPq by the bidding sheet MCT /CNPq/MS-SCTIE-DECIT 24/2006 - Estudos em Populações Expostas à Contaminação Ambiental, Processo n. 409845/2006-0. Report of the Research Ethics Committee (CEP): Report conceived through the Research Ethics Committee of Escola de Saúde Pública do Ceará (Consubstantiated report n. 53/2007)

Conflict of interests: nothing to declare.

\section{Abstract}

The lower valley of Jaguaribe has registered, since the XXI century, the arrival of transnational and regional companies, which led to deep transformations in this region. The increased use of the pesticides is one of the most important ones, being able to cause alterations in human procreation and leading to congenital deformations, besides premature birth and low weight newborns. This article is an ecological study related to the period from 2000 to 2010 in the population of some cities in the state of Ceará, and it was divided in two parts: the first one, a draft of historical series of morbidity and mortality databases and trend verification performed by a simple linear regression; the second one comprehends the calculation of the ratio of rates between cities that are highly exposed to pestiides and the cities selected for comparison, with history of little use of these substances. There was statistically considerable growth tendency ( $p=0.026)$ in the number of hospitalized people with neoplasms. Analyzing the ratios of the rates in these same indicators, it is observed that the rates of hospitalized people with neoplasms were 1.76 times higher in the studied cities than in control cities $(\mathrm{p}<0.0010)$. With regard to to fetal deaths, a statistically considerable increase was observed $(p<0.05)$ as to the mortality rates in the studied cities. Results suggest there was higher morbidity and mortality caused by neoplasms in the cities with broader use of pesticides, which could be influenced by production, environmental and social transformations associated to the process of deterritorialization induced by the expansion of the agricultural modernization over the morbidity and mortality profile of the population of lower Jaguaribe. This process is a reflex of the production chemical-dependent model adopted by the agribusiness companies, expanding the vulnerability of the country side population.

Keywords: Pesticides. Environmental exposure. Neoplasms. Congenital abnormalities. Fetal death. Occupational health. 


\section{Resumo}

O Baixo vale do Jaguaribe registra, a partir do século XXI, a chegada de empresas transnacionais e regionais, induzindo profundas transformações nos territórios, sendo a ampliação do uso de agrotóxicos uma das mais importantes, podendo provocar alterações na reprodução humana, malformações congênitas, além de partos prematuros e recém-nascidos de baixo peso. $O$ presente artigo trata-se de um estudo ecológico, referente ao período de 2000 a 2010, conduzido em alguns municípios do Estado do Ceará, que foi dividido em duas fases: a primeira consiste na construção de séries históricas de indicadores de morbimortalidade e verificação da tendência realizada por meio de regressão linear simples; a segunda compreende o cálculo das razões das taxas entre municípios com alta exposição aos agrotóxicos e municípios de comparação com histórico de pouco uso dessas substâncias. Houve tendência de aumento estatisticamente significante $(\mathrm{p}=0,026)$ das taxas de internações por neoplasias. Ao se analisar as razões de taxas desses mesmos indicadores percebe-se que a taxa de internações por neoplasias foi 1,76 vezes maior nos municípios de estudo em relação aos municípios controle $(\mathrm{p}<0,001)$. Em relação aos óbitos fetais, observou-se uma tendência crescente $(\mathrm{p}<0,05)$ da taxa de mortalidade nos municípios estudados. Os resultados sugerem que houve uma maior morbimortalidade por neoplasias nos municípios com maior consumo de agrotóxicos, podendo ser influenciados pelas transformações produtivas, ambientais e sociais associadas ao processo de desterritorialização induzido pela expansão da modernização agrícola sobre o perfil de morbimortalidade da população do baixo Jaguaribe. Esse processo é reflexo do modelo produtivo químico-dependente incorporado pelas empresas do agronegócio, ampliando a vulnerabilidade da população rural.

Palavras-chave: Praguicidas. Exposição ambiental. Neoplasias. Anormalidades congênitas. Morte fetal. Saúde do trabalhador.

\section{Introduction}

The Lower valley of Jaguaribe, located near the border of Ceará and Rio Grande do Norte, has been a place of agricultural activities for at least four centuries, mainly developed in small properties that produced fruit, cotton and carnauba was, besides extensive cattle farming, in the different economic cycles. From the 1980s on, the region began to receive irrigation projects implemented by federal policies addressing the fight against drought, thus amplifying the agricultural activity ${ }^{1}$.

The XXI century as an expression of productive and socio-spatial restructuration registers the arrival of major transnational and regional companies of irrigated fruit farming for exportation, which induced a deterritorialization process in the region. This led to deep transformations in the agrarian and economic issues, which have a direct reflection on work relations and conditions, as well as environment and, consequently, the health of the population ${ }^{2}$.

If the Green Revolution had introduced new technological risks to the region from the 1970s on, such as the mechanization and the use of agrochemicals, the arrival of business agriculture reordered the space, inserting the companies in the surroundings of rural communities. This led to the creation of a segment of rural workers, employees of the agribusiness. These changes in the social conditions in which people live and work, or in the process of social reproduction ${ }^{3}$, determine the vulnerability and the health-disease of population groups.

One of the important dimensions of these transformations in the Lower valley of Jaguaribe concerns the increased use of pesticides associated to the production model that eliminates biodiversity to implement major extensions of intensive fruit monoculture. The Estudo epidemiológico da população da região do Baixo Jaguaribe exposta à contaminação ambiental em área de uso de agrotóxicos, conducted between 2007 and 2011, analyzed this matter as the object of study in the Jaguaribe cities of Limoeiro do Norte, Quixeré and Russas. 
From the point of view of environmental exposure to pesticides, it is important to consider the contiguity between the communities and the production areas, which creates the possibility of direct contamination of some households in bordering zones; the practice of air pulverization with fungicide of toxicological classes 1 and 2 in the extensive banana cultivations inserted among rural communities; and the contamination of water for human consumption by the different forms of pulverization and the inadequate disposal of pesticide packages. The studies conducted by the State department of hydric resources found the presence of pesticides in 6 out of the 10 water samples from the Aquifer Jandaíra, and the analyses in the scope of this study showed from 3 to 12 active ingredients in all of the 23 collected samples, involving subterranean waters and those distributed by the municipal service for the consumption of families ${ }^{4}$.

There is growing risk perception and concern with regard to health effects among workers, their families, inhabitants of companies' surroundings and social movements in the regions. However, further studies are necessary to quantitatively record this reality. Indeed, scientific literature has been pointing out to a diversified number of chronic effects of the pesticides, according to the specific toxicity of each one of the more than 400 Active Ingredients (AI) registered in Brazil, despite the scarce knowledge about multiple exposures, which correspond to the most frequent reality in the field ${ }^{5}$. Such effects can compromise, for instance, the nervous system, causing from neurobehavioral changes to encephalopathies or suicide $\mathrm{e}^{6-8}$; or the respiratory system, causing from asthma to pulmonary fibrosis; chronic toxic hepathopathies $^{8-10}$.

Concerning neoplasms, the pesticides associated with changes in hematopoiesis and chromosomes of the cells that can progress to myelodysplastic syndrome or myeloid leukemia and non-Hodgkin's lymphoma ${ }^{11,12}$. Studies demonstrate the existence of associations between pesticides and cancer affecting the lung, stomach, melanoma, prostate, brain, testicles and sarcomas $^{13,14}$. Besides, changes in human reproduction are also mentioned, such as male infertility, abortion, congenital malformations, premature labor, low-weight newborns, all of which are associated with the effects of endocrine interference and immunogenetics of some $\mathrm{AI}^{14-16}$.

Therefore, the objective of this study was to compare morbidity and mortality indicators by some of these chronic effects related to pesticides between cities of two distinct groups: (1) Case group: Limoeiro do Norte, Quixeré and Russas, where, since the year 2000, agribusiness activities and the intensive use of pesticides and mechanization have been increasing; (2) Control group: 12 cities with similar populations, where only traditional semiarid family agriculture is developed, called dry land farming. In the mentioned group, pesticides are not widely used, even because of the low purchasing power of the peasants, besides the sporadic use of agricultural machines.

\section{Methodology}

It is a quantitative, ecological study concerning the period from 2000 to 2010, which was conducted in cities in the state of Ceará and organized in two steps: in the first one, a study design of historical series of morbidity and mortality selected indexes and, in the second one, comparisons between these indicators in the cities of Groups 1 and 2 by means of ratio of rates.

Group 1 (case) comprehends the citis of Limoeiro do Norte, Quixeré and Russas, known for the intensive use of pesticides. Group 2 (control) is comprised of other cities belonging to the other agropoles in the State of Ceará that do not extensively use pesticides for farming. For the selection of the 11 control cities, it was chosen to pair the study cities according to population size and similarities between some of the main sociodemographic characteristics, such as literacy, sanitation conditions and mean monthly income. A ratio of 4:1 was used ( 4 control cities for each case city), except for the city of Russas, in which the ratio was of 3:1 due to the inexistence of control cities that met the selection criteria. The study cities with their respective controls, the agropoles to which they belong to and their populations are found in Figure 1. 
Indicators were built by estimating the mean rates of study cities and mean rates of comparison cities. For that, the numerators included hospital admissions and deaths caused by neoplasms selected from Chapter II (Neoplasms [tumors]) of CID-10, fetal death (Chapter XV of CID-10 - Group 08: pregnancy ending in abortion) and live births with malformation (Chapter XVII of CID10 - Congenital malformations deformities and chromosomal anomalies). In denominators, the population at risk was used, that is, the one from which cases originated. Data concerning hospital admissions caused by neoplasms were obtained from the data base of the Hospital Information System (SIH) ${ }^{17}$, and deaths were provided by the Mortality Information System (SIM) ${ }^{18}$. Fetal deaths and live births with malformations were obtained from the Live Birth Information System (SINASC) ${ }^{19}$. Estimates of the population living in the selected cities were provided by the Brazilian Institute of Geography and Statistics (IBGE) ${ }^{20}$.

Rates were calculated by the following formulas:

Rate of hospitalization for neoplasms $=$ N. Hospitalization Neoplasm $\times 10,000$

Population in the middle of the period

Mortality rate for neoplasms $=$

N. of deaths for Neoplasms $\times 100,000$

Population in the middle of the period

Fetal death rate $=$

N. of deaths in the gestational period $\times 1,000$

Total of live births in the period
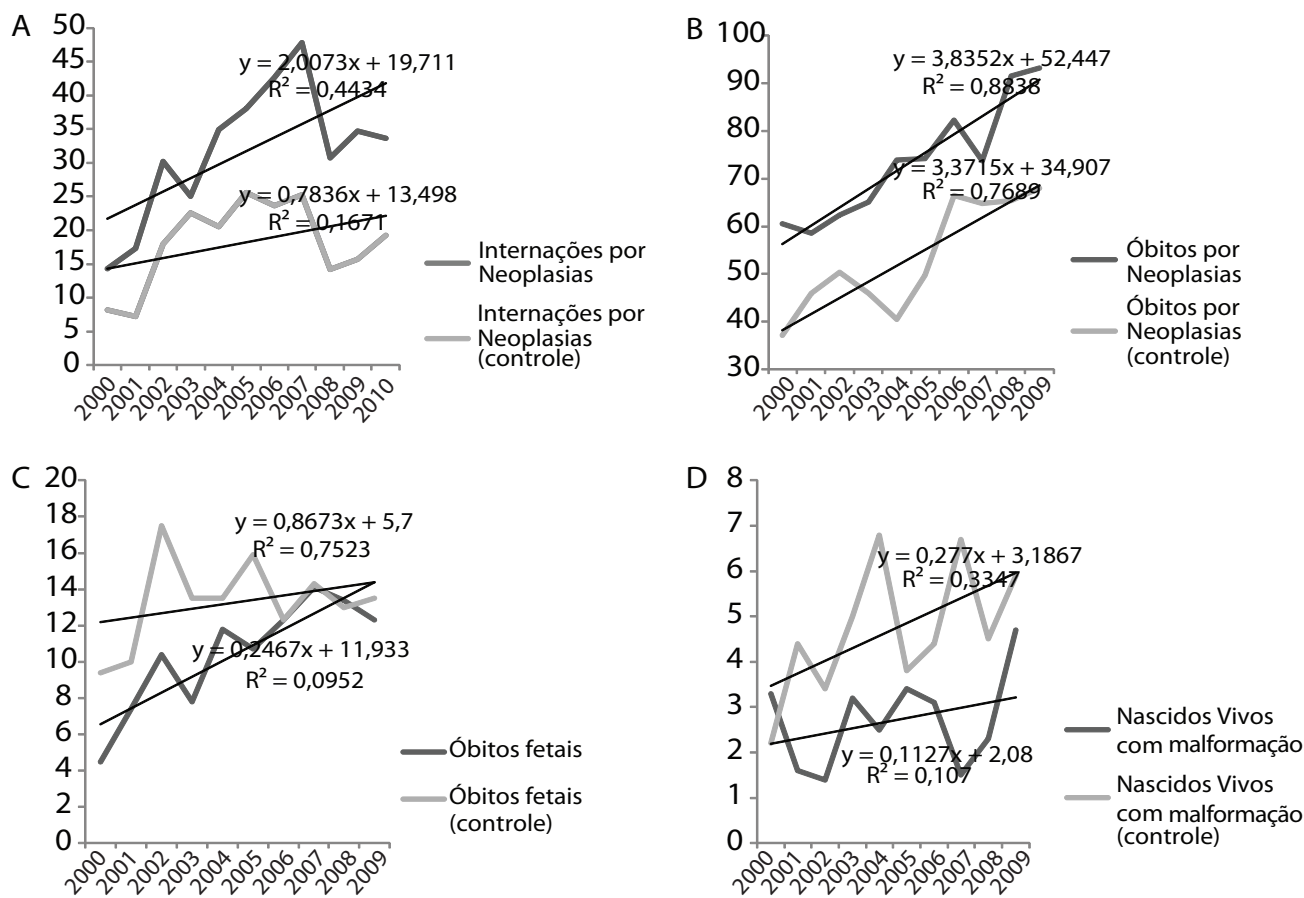

\footnotetext{
(A) Hospitalizations caused by neoplasm in the study and control cities, 2000 to 2010

(B) Mortality caused by neoplasm in the study and control cities, 2000 to 2009

(C) Fetal deaths in the study and control cities, 2000 to 2009

(D) Live Births with Congenital Malformation in study and control cities, 2000 a 2009
}

Figure 1 - Trends in rates of some selected diseases morbidity and mortality study of municipalities, Ceará, from 2000 to 2010.

Figura 1 - Tendências de taxas de alguns agravos selecionados de morbidade e mortalidade dos municípios de estudo, Ceará, 2000 a 2010. 
Malformation rate $=$

N. of live births with malformation $\times 1,000$

Total of live births in the period

Afterwards, there was the calculation and the standardization of hospitalization and mortality rates caused by neoplasms by the direct method, considering as the standard population the mean of the population in the state of Ceará in the period. This standardization was necessary, because the distribution of age groups between cities is not homogeneous.

The trend analysis of the rates $\left(1^{\text {st }}\right.$ stage $)$ was conducted by means of simple linear regression models. The construction of dispersion diagrams of the rates and years of study showed, in all of the cases, that the supposition of a linear evolution could be assumed, which justified the use of linear models. Statistical modeling considered each mean rate of the analyzed outcomes as a dependent variable, and chronological time (from 2000 to 2010) as an independent variable. In this sense, simple linear regression models were adjusted for each temporal series. The choice was to centralize the independent variable by subtracting the mid-point of each values in the series (X-2005), in order to avoid the self-correlation between the terms of the regression equation. Therefore, the estimated model can be written as: $Y=\beta_{0}+\beta_{1}(X-2005)$. In these models, $Y$ corresponds to morbidity or mortality rates, $\beta_{0}$, annual average coefficient; $\beta_{1}$ coefficient of linear effect (velocity) and $\mathrm{X}$, year. The trend was considered to be significant when the model obtained $\mathrm{p}<0.05$. As the precision measurement of the models, the coefficient of determination was used $\left(\mathrm{R}^{2}\right)^{21-25}$.

In the second stage, contingency tables were built to calculate the Ratios of Rates in the cities of Group 1, which did not use pesticides intensively (Limoeiro do Norte, Russas and Quixeré), divided by rates in Group 2 (control), and the latter refer to the ones that did not use pesticides intensively, as demonstrated in Table 3 . The ratios of rate and $95 \%$ Confidence Interval (95\%CI) were estimated by the Mantel-Haenszel method for the $\mathrm{p}$ value and $95 \% \mathrm{CI}$. For all the analyses, the adopted significance level was $\mathrm{p}<0.05$.

\section{Results}

The study cities and the comparison cities, with their respective populations, are found in Table 1. The historical series of rates are found in Table 2 and Figure 1. For the indicators elaborated with SIM data, there were no available data for 2010 .

\section{Neoplasms}

There was an increasing trend in the hospitalization rate caused by neoplasms in Group 1 $(\mathrm{p}=0.026)$. However, in Group 2, these rates stabilized, with low angular coefficient ( 0.78$)$ with no statistical significance $(\mathrm{p}>0.05)$ (Table 3; Figure 1).

Table 1 - Municipalities and their populations selected for study, Ceará, 2010.

Tabela 1 - Municípios e respectivas populações selecionadas para o estudo, Ceará, 2010.

\begin{tabular}{lccc}
\hline $\begin{array}{l}\text { Group } 1 \\
\text { (Case) }\end{array}$ & Population & $\begin{array}{c}\text { Group 2 } \\
\text { (Control) }\end{array}$ & Population \\
\hline \multirow{2}{*}{ Russas } & 69,833 & Aracati & 69,159 \\
& & Crateús & 72,812 \\
& & Pacatuba & 72,299 \\
Quixeré & 19,412 & Caridade & 20,020 \\
& & Morrinhos & 20,700 \\
& & Quiterianópolis & 19,921 \\
Limoeiro do Norte & Morrinhos & 20,700 \\
& \multirow{2}{*}{56,264} & Santa Quitéria & 42,763 \\
& & Trairi & 51,422 \\
& & Boa Viagem & 52,498 \\
\end{tabular}


Table 2 - Average rates of hospitalizations and deaths of control municipalities and other municipalities, Ceará, from 2000 to 2010.

Tabela 2 - Taxas médias de internações e óbitos dos municípios controle e demais municípios, Ceará, 2000 a 2010.

\begin{tabular}{|c|c|c|c|c|c|c|c|c|}
\hline Year & $\begin{array}{l}\text { Hospitalizations } \\
\text { per Neoplasms }\end{array}$ & $\begin{array}{l}\text { Hospitalizations } \\
\text { per neoplasms } \\
\text { (control) }\end{array}$ & $\begin{array}{c}\text { Deaths per } \\
\text { neoplasms }^{\mathrm{b} *}\end{array}$ & $\begin{array}{c}\text { Deaths per } \\
\text { neoplasms }^{\text {b }} \\
\text { (control) }^{*}\end{array}$ & $\begin{array}{c}\text { Fetal } \\
\text { deaths }{ }^{c *}\end{array}$ & $\begin{array}{c}\text { Fetal } \\
\text { deaths }^{c} \\
(\text { control)* }\end{array}$ & $\begin{array}{c}\text { Live births } \\
\text { with } \\
\text { malformation }{ }^{\text {c* }}\end{array}$ & $\begin{array}{l}\text { Live births with } \\
\text { malformation } \\
\text { (control) }^{* *}\end{array}$ \\
\hline 2000 & 14 & 8 & 60 & 37 & 4 & 9 & 3 & 2 \\
\hline 2001 & 17 & 7 & 58 & 46 & 7 & 10 & 1 & 4 \\
\hline 2002 & 30 & 18 & 62 & 50 & 10 & 17 & 1 & 3 \\
\hline 2003 & 25 & 22 & 65 & 46 & 7 & 13 & 3 & 5 \\
\hline 2004 & 34 & 20 & 73 & 40 & 11 & 13 & 2 & 6 \\
\hline 2005 & 38 & 25 & 74 & 49 & 10 & 15 & 3 & 3 \\
\hline 2006 & 42 & 23 & 82 & 66 & 12 & 12 & 3 & 4 \\
\hline 2007 & 47 & 25 & 73 & 64 & 14 & 14 & 1 & 6 \\
\hline 2008 & 30 & 14 & 91 & 65 & 13 & 13 & 2 & 4 \\
\hline 2009 & 34 & 15 & 93 & 68 & 12 & 13 & 4 & 5 \\
\hline 2010 & 33 & 19 & - & - & - & - & & \\
\hline
\end{tabular}

*Data available up to the year 2009. aPer 10.000 inhabitants; ${ }^{b} P e r 100.000$ inhabitants; 'Per 1.000 live births.

*Dados disponíveis ate o ano de 2009. aPor 10.000 habitantes; ${ }^{b}$ Por 100.000 habitantes; ${ }^{\text {CPor }} 1.000$ nascidos vivos.

Concerning mortality rates caused by neoplasm, it is possible to observe that both the trends in Group 1 and in Group 2 were increasing $(\mathrm{p}<0.001)$. However, the mean coefficients and the angular coefficients of the trends in the study cities $\left(\beta_{0}=52.45\right.$ and $\beta_{1}=3.83$ ) were higher than for control cities $\left(\beta_{0}=34.89\right.$ and $\left.\beta_{1}=3.37\right)$, which indicates greater magnitude of the annual increment of the trends in rates of study cities in relation to the trend of the others.

\section{Fetal death}

As to fetal death, an increasing and statistically significant trend is observed $(\mathrm{p}<0.05)$ in mortality rates of the study cities. With regard to control cities, even though the beginning of the historical series presented higher rates, the temporal evolution of these indicators leaned to stability ( $p>0.05)$. In relation to congenital malformation, trends were stable for all of the studied groups ( $p>0.05)$.

\section{Association}

After analyzing the ratios of rates in these same indicators, it is observed that the rate of hospitalizations caused by neoplasms was 1.76 times higher in Group 1 in comparison to Group 2 ( $\mathrm{p}<0.001)$. Likewise, the mortality rate due to neoplasms was also higher in the study cities $(\mathrm{OR}=1.38 ; \mathrm{p}=0.007)$. However, there were no statistically significant differences in the comparison of rates of fetal death ( $p>0.05)$ and live births with fetal malformation $(\mathrm{p}>0.05)$.

\section{Discussion}

The results of the analyses conducted in the group of cities who are undergoing a process of agriculture modernization, by expanding the agribusiness activities and the intensive use of pesticides, when compared to the group of cities who are based on traditional family agriculture, popularly known as dry land farming, show a growing trend, with positive variation indicating the annual increment for hospitalizations and deaths caused by neoplasm and fetal deaths.

The most common association between pesticides and different types of cancer among agriculturalists are the ones affecting the hematopoietic system - non-Hodgkin's lymphoma, multiple myeloma and leukemia; besides lung, stomach, melanomas, prostate, brain, testicles and sarcomas ${ }^{13-14}$.

Brazil has been going through transformations in its population structure and in the morbidity and mortality standards in the late $20^{\text {th }}$ century. The population 
Table 3 - Estimates related to the linear regression of selected municipalities in the study and control Ceará, from 2000 to 2010.

Tabela 3 - Estimativas referentes à equação de regressão linear de indicadores selecionados nos municípios de estudo e controle - Ceará, 2000 a 2010.

\begin{tabular}{lccc}
\hline Morbidity & $\beta^{-}{ }_{1}$ & $\mathrm{p}$-value & $\mathrm{R}^{2}$ \\
\hline $\begin{array}{l}\text { Hospitalizations caused by neoplasms } \\
\text { (per 10,000 inhabitants) }\end{array}$ & & & \\
$\quad$ Study cities & 2.00 & 0.026 & 0.44 \\
$\quad$ Control cities & 0.78 & 0.214 & 0.16 \\
$\begin{array}{l}\text { Deaths caused by neoplasms* } \\
\text { (per 100,000 inhabitants) }\end{array}$ & & & \\
$\quad$ Study cities & 3.83 & $<0.001$ & 0.88 \\
$\quad$ Control cities & 3.37 & 0.001 & 0.77 \\
Fetal deaths & & & \\
(per 1,000 live births) & & & \\
$\quad$ Study cities & & 0.001 & 0.75 \\
$\quad$ Control cities & 0.86 & 0.377 & 0.10 \\
Live births with malformation ${ }^{*}$ & 0.25 & & \\
$\quad$ (per 1,000 live births) & & & \\
$\quad$ Study cities & & 0.368 & 0.10 \\
$\quad$ Control cities & 0.11 & 0.76 & 0.34 \\
\hline
\end{tabular}

*Data available up to the year 2009.

*Dados disponíveis ate o ano de 2009.

Tabela 4 - Razões de taxas de indicadores selecionados nos municípios de estudo e controle Ceará, 2000 a 2010.

Table 4 - Odds Ratio of selected municipalities in the study and control - Ceará, from 2000 to 2010.

\begin{tabular}{lccc}
\hline Indicators & Rate & $\begin{array}{c}\text { Ratio of rates } \\
(95 \% \mathrm{Cl})\end{array}$ & p-value \\
\hline $\begin{array}{l}\text { Hospitalizations caused by neoplasms** } \\
\text { (per 10,000 inhabitants) }\end{array}$ & 18.3 & & \\
$\quad$ Control cities & 32.2 & $1.76(1.57-1.97)$ & $<0.001$ \\
$\quad \begin{array}{l}\text { Study cities } \\
\text { Deaths caused by neoplasms* } \\
\text { (per 100,000 inhabitants) }\end{array}$ & & & \\
$\quad$ Control cities & 53.9 & 1.00 & \\
$\quad$ Study cities & 74.3 & $1.38(1.09-1.73)$ & 0.007 \\
$\begin{array}{l}\text { Fetal deaths* } \\
\text { (per } 1,000 \text { live births) }\end{array}$ & & & \\
$\quad \begin{array}{l}\text { Control cities } \\
\quad \text { Study cities }\end{array}$ & 13.4 & 1.00 & \\
Live births with malformations* & 10.3 & $0.77(0.49-1.21)$ & 0.258 \\
(per 1,000 live births) & & & \\
$\quad \begin{array}{l}\text { Control cities } \\
\text { Study cities }\end{array}$ & 4.6 & $0.60(0.25-1.40)$ & 0.231 \\
\hline
\end{tabular}

*Data available up to the year 2009; **Economically active population.

*Dados disponiveis ate o ano de 2009; **População economicamente ativa.

is aging and there is constant increase in the prevalence and mortality of chronicdegenerative diseases, among which are the neoplasms. However, the growing trends of hospitalization and death rates in the study cities suggest more environmental exposure, including to pesticides.

In order to illustrate the complexity and vulnerability of the rural workers in association with the problem of pesticide 
use, only for the use of pesticides in Brazil, a bibliographic study ${ }^{8}$ was conducted involving national studies from 2000 to 2005 . These studies found: submission to poor working conditions; low schooling; increased risk for socioeconomic factors; Personal Protective Equipment (PPE) (inadequate, unavailable or unused); exposure of women at fertile age; exposure of young adults aged less than 20 years old; being guided only by a salesman; improper destination of packages; little awareness about the risk of products; use of class I products; re-entry in the postapplication area; increased exposure load.

Agriculturists are considered as a group more prone to cancer, considering the productive context in which they are inserted, since they handle directly with poisons in the several activities they perform. Some examples: appliers, harvesters, transporters, factory staff, mixers of toxic products, packers ${ }^{26}$.

There is a whole context of vulnerability and noxiousness that involves the use of pesticides, which ranges from the occult damage to human health (clinical and subclinical effects) and to the environment. This exposure scale presents historical difficulties to make control, monitoring and assessment of risks effective, as well as to analyze the damage associated with the toxicity of the pesticides, the access to inexistent supporting technologies, or ones that are little available in public services ${ }^{21}$.

In a recent review of the epidemiological evidence related to the occupational exposure to pesticides and the incidence of cancer in the Agricultural Health Study (AHS), a study ${ }^{25}$ examined 32 approved pesticides in the United States and Canada in order to assess the potential of exposure-response relations. In 12 out of the 32 analyzed pesticides (37.5\%), there was increased rate of cancer incidence, besides the patterns of positive response-exposure.

In Ceará, a cross-sectional study about the registered cases of cancer among rural workers revealed increased risk of penis cancer (6.44/1000), leukemia (6.35) and testicles
(5.77), besides other locations with risk ranging from 1.88 to 1.12 (urinary bladder, multiple myeloma, lymphoma, conjunctive tissue, eyes and surroundings, esophagus, colon rectosigmoid junction, kidney, larynx, prostate and thyroid $(95 \% \mathrm{CI})^{26}$.

In a study conducted in the region of Vale do São Francisco, it was observed that mortality caused by cancer is associated with the use of pesticides among rural workers ${ }^{27}$. The International Agency for Research on Cancer (IARC) classified the organochlorines as being carcinogens for the human species.

Data of mortality caused by cancer were analyzed in the mountain region of Rio de Janeiro, and showed high incidence of death by stomach, esophageal and larynx cancer among male agriculturists from 1979 to 1998, when compared to other male populations in the same age group ${ }^{10}$. Another author ${ }^{28}$ studied the prevalence of mortality caused by neoplasms in the region of Ijuí (RS) and compared data from the state of Rio Grande do Sul and Brazil. He observed that men die more of cancer than women in the three studied places, considering that such fact is owed to the higher occupational exposure of the man in the rural work.

There are many difficulties to establish the relationship between cancer and the exposure to pesticides, despite the recognized carcinogen power of these biocides. However, these studies can corroborate the result that shows significant increase in hospitalization and death rates caused by neoplasms in the cities in this study to the detriment of other studied cities that do not intensively use pesticides ${ }^{29}$.

The results that reveal a growing and significant trend in fetal death rate in the cities going through an agriculture modernization process can also indicate the association between the occupation of the parents in agriculture and the exposure to pesticides. The research showed the association between fetal death and father occupation in agriculture in areas and periods with different levels of pesticide use. The families of agriculturists had more chances 
of experiencing pregnancies wit fetal death (including congenital anomalies) in areas where pesticides are massively used when compared to other regions of the country. The study also showed the increased risk of fetal death when the period of maximum use of pesticides coincides with the moment of conception.

In Brazil and Latin America, deaths caused by congenital malformation in the first year of life have been increasing, as what happens in developed countries, and is now considered as a relevant aspect for public health ${ }^{30}$. It was expected to find growing trends in the rates of live births with congenital malformation in the studied cities. In this case, it is not recommended to hide the fact that the excessive number (not measured) of spontaneous abortions that are common in these pregnancies may have biased these trends to stability. Besides, the growing trend of fetal death in the studied cities can also explain the stabilization of rates. In this direction, studies suggest possible risks in the relation with gestational exposure to pesticides. Even though it did not represent statistical significance, this association is suggested as a decisive factor for the occurrence of congenital defects by reading variables such as: both parents working in farming and living nearby, mother living next to farming, father working in farming, father using the products for farming and exposure of at least one of the parents ${ }^{31}$.

In another study ${ }^{32}$ conducted in Denmark, the occupational exposure of pregnant women to pesticides as being the cause of adverse effects in the reproductional development of male children was investigated. The research analyzed 113 pairs (mother-child) divided into occupationally exposed (91) and non-exposed (22) to pesticides during pregnancy. It was shown that women working in the rural area, confirmedly exposed to pesticides during pregnancy, had children with smaller penises and testicles, lower concentration of serum testosterone and Inhibin $\mathrm{B}$, higher concentration of serum SHBG and FSH and higher LH:testosterone ratio in comparison to non-exposed workers, which suggests the adverse effect of pesticides in Leydig and Sertoli cells during testicular development ${ }^{33}$.

In this paper, rates of hospitalization caused by neoplasms were used as indicators of morbidity. Authors34 point out that SIH, where all of the information comes from, uses the Authorization for Hospital Admission (AIH) as a unit of analysis, and not the ill patient. Since the same person can be hospitalized more than once, or even not be hospitalized, even if being sick, because of limitations in hospital structure, the fragility consists on the use of hospitalizations as an approximation of the number of cases of the condition. However, this has been pointed out as one of the best indicators of the effects to chronic diseases. On the other hand, the participation of the supplementary health system is not relevant in the region, even in cities in which SUS is in charge of $100 \%$ of outpatient and hospital care. Because of that, the data used in the study cover most of the population.

In ecological studies, measures of aggregate exposure and disease are compared, and there is no information about the disease and exposure of the subject, but of the entire population group. Even though an ecological association may properly reflect a causal association between exposure and disease/ condition related to health, it is not possible to rule out the possibility of ecological fallacy, because an association observed among aggregates does not necessarily mean that the same association should occur among individuals ${ }^{35-36}$

\section{Final considerations}

The mentioned results suggest the influence of productive, environmental and social transformations associated with the deterritorialization process induced by the expansion of agriculture modernization on the profile of morbidity and mortality of the population in the lower Jaguaribe. This is a reflex of the chemical-dependent model of production 
adopted by agribusiness companies and the increased vulnerability of the population.

From the point of view of health, it is necessary to question if such expansion, as suggested by these data, which increases cancer and fetal death rates in the population, should be recognized as development.

According to the authors" ${ }^{36}$ : "Consultations to scientific production about pesticides and cancer show many studies that document this relation and suggest the causal nature of many of the described associations, which are now facilitated by methods of molecular biology and cytogenetics. However, knowledge gaps or limitations in the replicability of the studies make researchers and institutions, such as the IARC and the World Health Organization
(WHO) cautious about stating possible causal nexus, pointing out to the need to increase scientific investigations in order to guide preventive intervention".

While the sociopolitical conditions are built to value precaution, studies should at least focus their efforts on assessing the effects of multiple exposure and low doses, two of the most cloudy dimensions of current ignorance; the Unified Health System (SUS) should be prepared to bring the processes of territorialization in health of the live dynamic of inter-relations closer to the work and the environment, and protect them; in order to care for these affected workers, it is important to recognize and notify their conditions and point out to its ethiology.

\section{References}

1. Sampaio JLF, Lima AEF, Freitas BMC. As bases geo-históricas do Baixo Jaguaribe. In: Rigotto RM. (org). Agrotóxicos, trabalho e saúde:vulnerabilidade e resistência no contexto da modernização agrícola no Baixo Jaguaribe/ CE. Fortaleza/São Paulo: Edições UFC-Expressão Popular; 2011. p. 111-43.

2. Freitas BMC. Marcas do agronegócio no território da Chapada do Apodi. In: Rigotto RM. (org). Agrotóxicos, trabalho e saúde: vulnerabilidade e resistência no contexto da modernização agrícola no Baixo Jaguaribe/CE. Fortaleza/ São Paulo: Edições UFC-Expressão Popular; 2011. p. 144-63.

3. Breilh J. Epidemiologia crítica: ciência emancipadora e interculturalidade. Rio de Janeiro: Fiocruz; 2006.

4. Marinho AMCP. Contextos e contornos da modernização agrícola em municípios do Baixo Jaguaribe - CE: o espelho do (des)envolvimento e seus reflexos na saúde, trabalho e ambiente. [Tese de Doutorado]. São Paulo: Faculdade de Saúde Pública da USP; 2010.

5. Matos GB, Santana OAM, Nobre LCC. Intoxicação por agrotóxicos. In: Manual de Normas e Procedimentos Técnicos para a Vigilância da Saúde do Trabalhador. Salvador: Secretaria de Saúde do Estado da Bahia; 2002. p. 249-80.

6. Levigard YE, Rozemberg B. A interpretação dos profissionais de saúde acerca das queixas de "nervos" no meio rural: uma aproximação ao problema das intoxicações por agrotóxicos. Cad Saude Publica 2004; 20(6): 1515-24.

7. Ramos A, Silva JF. Exposição a pesticidas, atividade laborativa e agravos à saúde. Rev Med Minas Gerais 2004; $14(1): 41-5$.
8. Faria NMX, Fassa AG, Facchini LA. Intoxicação por agrotóxicos no Brasil: os sistemas oficiais de informação e desafios para a realização de estudos epidemiológicos. Cienc Saude Coletiva 2007; 12(1): 25-38.

9. Organização Pan-americana da Saúde (OPAS). Manual de Vigilância da Saúde de Populações Expostas a Agrotóxicos. Brasília: Organização Pan-americama da Saúde; 1996.

10. Meyer A, Sarcinelli PN, Abreu-Vilaça Y, Moreira JC. Os agrotóxicos e sua ação como desreguladores endócrinos. In: Peres F, Moreira JC. É veneno ou é remédio: agrotóxicos, saúde e ambiente. Rio de Janeiro: Fiocruz; 2003. p.101-20.

11. Instituto Nacional de Câncer (INCA). Vigilância do câncer e de fatores de risco. Disponivel em: http://wwwl.inca.gov.br/ vigilancia/. (Acessado em 9 de julho de 2011).

12. Miligi L, Costantini AS, Veraldi A, Benvenuti A; WILL, Vineis P. Cancer and pesticides: an overview and some results of the Italian multicenter case-control study on hematolymphopoietic malignancies. A N Y Acad Sci 2006; 1076: 366-77.

13. Pimentel LCF. O inacreditável emprego de produtos químicos perigosos no passado. Química Nova 2006; 29(5): 1138-49.

14. Grisolia CK. Agrotóxicos - mutações, câncer e reprodução. Brasília: Universidade de Brasília; 2005.

15. Romano RM, Romano MA, Moura MO, Oliveira CA. A exposição ao glifosato-Roundup causa atraso no início da puberdade em ratos machos. Braz J Vet Res Anim Sci 2008; 45(6): 481-7. 
16. Fontenele EGP, Martins MRA, Quiduti ARP, Montenegro Jr. RM. Contaminantes ambientais e os interferentes endócrinos. Arq Bras Endocrinol Metab 2010; 54(1): 6-16.

17. Ministério da Saúde. Datasus. Sistema de Informações Hospitalares - Morbidade Hospitalar do SUS - por local de residência - Ceará. [citado 2012 mar 13]. Disponível em: <http://tabnet.datasus.gov.br/cgi/deftohtm.exe?sih/cnv/ nrce.def>.

18. Ministério da Saúde. Datasus. Sistema de Informações de Mortalidade - Mortalidade por local de residência - Ceará. [citado 2012 mar 13]. Disponível em: <http://tabnet.datasus. gov.br/cgi/deftohtm.exe?sim/cnv/obt10ma.def $>$.

19. Ministério da Saúde. Datasus. Sistema de Informação de Nascidos Vivos. Disponivel em: http://tabnet.datasus.gov. br/cgi/deftohtm.exe?sinasc/cnv/nvCE.def. (Acessado em 13 de março de 2012).

20. Instituto Brasileiro de Geografia e Estatística. Sistema IBGE de Recuperação Automática. Banco de Dados Agregados. Disponivel em: http://www.sidra.ibge.gov.br/bda/acervo/default. asp? $\mathrm{z}=\mathrm{t} \& \mathrm{o}=3 \& \mathrm{i}=\mathrm{Ph} t \mathrm{tp}$. (Acessado em 13 de março de 2012).

21. Morgenstern H. Ecologic studies. In: Rothman KJ;Greenland S. 2nd ed. Modern epidemiology. Philadelphia: LippincottRaven Publishers; 1998.

22. Boyle P, Parkin DM. Statistical methods for registries. In: Jensen OM, Parkin DM, Maclennan R, Muir CS, Skeet RG. (eds.). Cancer Registration - principles and Methods. Lyon: International Agency for Research on Cancer (IARC). IARC Scientific Publications n. 95; 1991. p. 126-58.

23. Kleinbaum DG, Kupper LL, Muller KE. Applied Regression Analysis and other Multivariable Methods. Belmont, California: PWS-KENT Publishing Company; 1988.

24. Morettin PA, Toloi CM. Séries Temporais. Coleção Métodos Quantitativos. São Paulo: Atual Editora; 1986.

25. Augusto LGS. Critical reflection on the invisibility of biosafety and biosecurity. Cienc Saude Coletiva 2012; 17(2):293-4.

26. Weichenthal S, Moase C, Chan P. A review of pesticide exposure and cancer incidence in the agricultural health study cohort. Cienc Saude Coletiva 2012; 17(1): 255-70.
27. Ellery AEL, Arregi MMU, Rigotto RM. Incidência de câncer em agricultores em hospital de câncer no Ceará. In: XVIII IEA World Congress of Epidemiology, VII Congresso Brasileiro de Epidemiologia. São Paulo: ABRASCO; 2008.

28. Bedor CNG. Estudo do potencial carcinogênico dos agrotóxicos empregados na fruticultura e sua implicação para a vigilância da saúde [tese de doutorado] Rio de Janeiro: Fundação Oswaldo Cruz; 2008.

29. Jobim PFC, Nunes LN, Giugliani R, Cruz IBM. Existe uma associação entre mortalidade por câncer e uso de agrotóxicos? Uma contribuição ao debate. Cienc Saude Coletiva 2010; 15(1): 277-88.

30. Silva SRG, Martins JL, Siexas S, Silva DCG, Lemos SPP, Lemos PVB. Defeitos congênitos e exposição a agrotóxicos no Vale do São Francisco. Rev Bras Ginecol Obstet 2011; 33(1): 20-6.

31. Andersen HR, Schmidt IM, Grandjean P, Jensen TK, BudtzJørgensen E, Kjaerstad MB, et al. Impaired reproductive development in sons of women occupationally exposed to pesticides during pregnancy. Environ Health Perspect 2008; 116(4): 566-72.

32. Laurenti R, Mello Jorge MHP, Lebrão ML, Gotlieb SL. Estatística de saúde. São Paulo: EPU; 1987.

33. Bittencourt SA, Camacho LA, Leal Mdo C. O Sistema de Informação Hospitalar e sua aplicação na saúde coletiva. Cad Saude Publica 2006; 22(1): 19-30.

34. Szklo M, Javier Nieto F. Basic study designs in analytical epidemiology. In: Szklo M, Javier Nieto F. Epidemiology: beyond the basics. Gaithersburg: Aspen Publishers; 2000. p. 3-51.

35. Morgenstern H. Ecologic studies. In: Rothman KJ, Greenland S. Modern epidemiology. Philadelphia: Lippincott-Raven; 1998. p. 459-80.

36. Rosa IF, Pessoa VM, Rigotto RM. Introdução: agrotóxicos, saúde humana e os caminhos do estudo epidemiológico. In: Rigotto RM. (org). Agrotóxicos, Trabalho e Saúde vulnerabilidade e resistência no contexto da modernização agrícola no Baixo Jaguaribe/CE. Fortaleza/São Paulo: Edições UFC - Expressão Popular; 2011. p. 217-56.

Received on: 04/30/2012

Final version presented on: 02/22/2013 Accepted on: 06/07/2013 